\title{
Transboundary water resources "A comparative study": The lessons learnt to help solve the Nile basin water conflict
}

\author{
Mohamed A. Ashour, Tawab E. Aly, Haitham M. Abueleyon \\ Department of Civil Engineering, Faculty of Engineering, Assiut University, 71515 Assiut, Egypt, e-mail: mashour475275@yahoo.com; \\ tawab_aly@yahoo.com (*corresponding author); haithammohamad1983@gmail.com
}

\begin{abstract}
The problematic water situation in Egypt, as one of the River Nile basin countries, has been heightened by the harmful effects of the Grand Ethiopian Renaissance Dam (GERD) on Egypt's share of the Nile water. In the light of this Egyptian attention was directed towards a study of worldwide transboundary water problems, in order to find the most effective methods for dealing successfully with water shortage problems in basin countries. The present study focuses on the most successful experiences in the management and development of international river basins worldwide, as well as studying the possibility of implementing these experiences in other basins, especially the River Nile basin. The study showed that overcoming the water scarcity problems in Egypt and increasing the Nile water yield for all the basin countries can be achieved, first of all through serious cooperation among all the basin countries for minimizing the huge water losses from the river (more than 1480 Billion Cubic Metres per year which represents roughly $90 \%$ of the whole basin income), and secondly to make use of the most successful technical and political experiences that have been implemented in other international river basins mentioned in the present study.
\end{abstract}

Key words: transboundary water, overcoming water scarcity, Nile water losses

\section{Introduction}

The complex nature of historical, political, economic, institutional and human interactions within transboundary river basins make the management of these shared water resources more difficult. Therefore, studying and analyzing the different experiences that have resulted in successful cooperation and sharing of international rivers is essential be in order to apply this knowledge to other transboundary water problems. Issues of increasing water scarcity, degrading water quality, rapid population growth and uneven levels of economic development worldwide, are commonly cited as potentially conflicting factors among the basin countries. Hence the effective management and planning of transboundary water can help in solving such problems through handling them not only with political solutions, such as water agreements and water institutions, but also with technical and modern engineering approaches or non-conventional water resources.

The primary goals of this paper are to study, analyze and highlight the most effective experiences applied in the management of transboundary river basins all over the world so as to compile a useful reference for solving international water sharing problems in other places, such as the Nile River basin, which are still to be resolved.

The methodology in this study was based on five phases; the first was to give an overview of worldwide conflicts over water in international river basins. The second was to identify the technical solutions introduced to overcome the problems of water scarcity in some basin countries. The third, to identify political solutions for conflict resolution in transboundary river basins by focusing on the most important transboundary river basin in each continent. The fourth phase aimed to analyse, discuss and compare the identified technical and political solutions implemented to solve international water sharing problems on each continent. The fifth phase gives a brief review of the Nile basin characteristics and situations and discusses the most effective solutions adopted in international river basins worldwide that could also be applicable in the Nile basin. 


\section{Conflicts over water in international river basins}

Transboundary river basins, which cover almost $50 \%$ of the land surface, serve nearly $40 \%$ of the world's population and provide about $60 \%$ of the global water discharge (Jansky 2004), can be a source of conflict or cooperation among the sharing countries. Conflicts over water in transboundary river basins may arise from a variety issues, such as natural flooding, natural droughts, political tension, or mistrust. Yoffe (2002) analysed 1831 water events covering 122 transboundary river basins worldwide during the period 1948-1999 and identified three categories of basins at risk of conflict due to freshwater resources as indicated in Figure 1.

The first category, about 3\% of the studied basins, were already objects of negotiation due to existing conflicts. These included the Aral Sea, the Jordan, Nile, and Tigris-Euphrates basins; these basins are well known as "hot spots", where the potential for future disputes is considered high. The second category, about $7 \%$ of the studied basins, were those with indicators for future conflicts and protests, among which are countries where development projects are planned, including Lake Chad, the Mekong, Okavango, Salween, Senegal, Kune, Indus, Han, Ganges, and Orontes basins. The third category, about $11 \%$ of the studied basins, were those with indicators for future conflicts but without any current protest or friction among the basin coun- tries. including the Ca, Chiloango, Cross, Drin, Irrawaddy, Kura-Araks, La Plata, Lempa, Limpopo, Ob, Red, Saigon, Song Vam Co Done, Yalu, and Zambezi basins. The rest of the basins studied by Yoffe, were not included in the previous categories as cooperative events in these basins outweighed conflictive events.

From the literature review it can be noticed that the negotiations for reaching such a political solutions take a long time while the problem is ongoing. Thus, techni$\mathrm{cal}$ and groundbreaking engineering solutions become very important to overcome the present and expected near future problems of water shortage in some of the river basin countries, until a favourable political solution or agreement is reached, which may take a long time.

\section{Technical solutions to overcome the problems of water scarcity}

Water shortage is recognized as a present and future threat to human activities in around $43 \%$ of the transboundary river basins all over the world (Escobar, 2010). This problem cannot be solved with political solutions only. Hence, technical solutions and engineering approaches, such as desalination, reuse of treated wastewater, Inter Basin Water Transfers (IBWTs), and Virtual Water Trade (VWT), can develop alternative "non-conventional" water resources to be handled side by side with political negotiations.

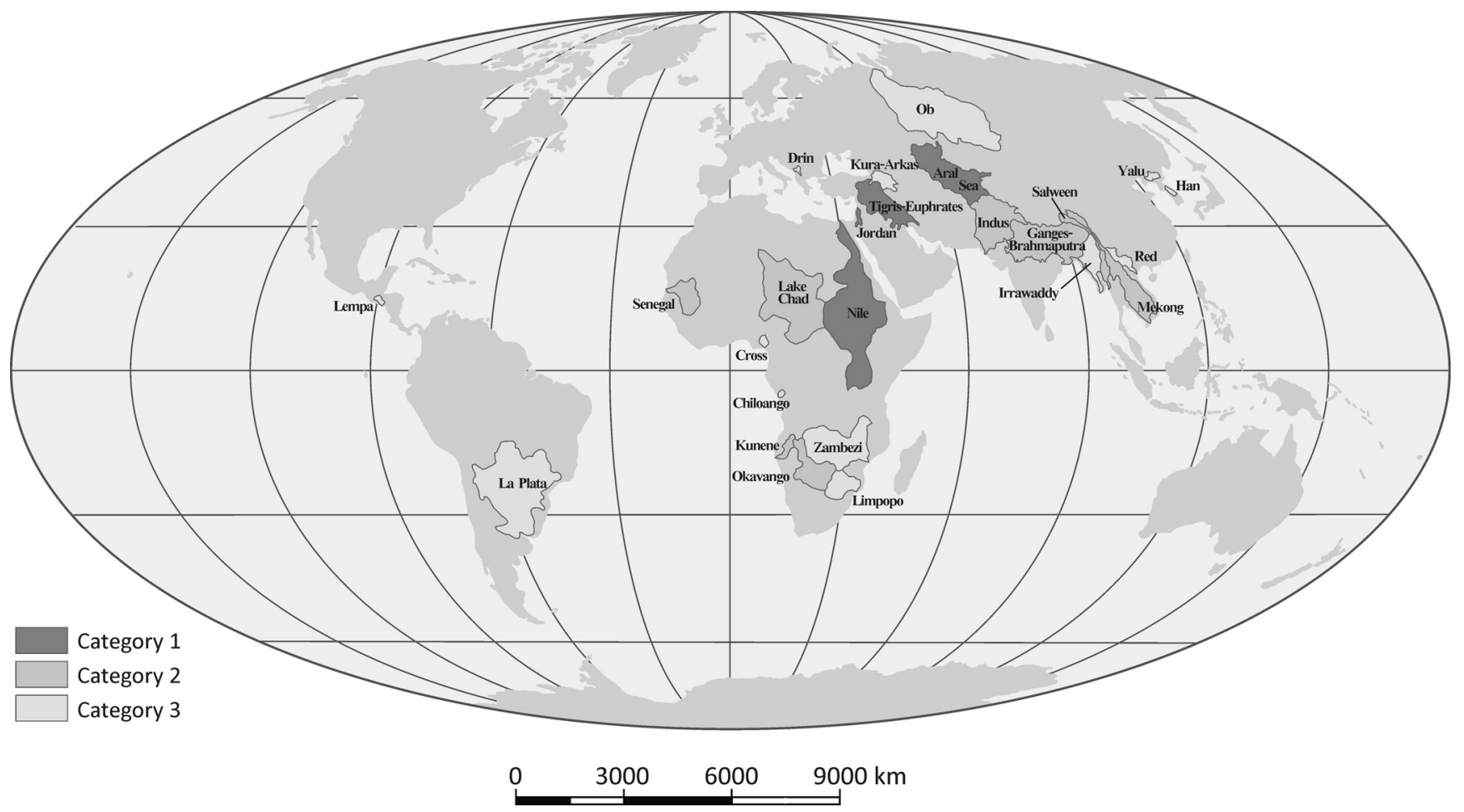

Fig. 1. Basins at risk of conflict (Yoffe 2002) 


\section{Desalination}

National water projects for desalination can be classified by their separation mechanisms into two common types; thermal and membrane desalinations. Amy and Lattemann (2017) reported that approximately 22500 desalination plants are operating around the world, of which around $60 \%$ are Reverse Osmosis (RO) membrane plants. The energy consumption of reverse osmosis plants is the lowest among all desalination options, making them more efficient in regions with high energy costs as a result of some technological innovations, such as the use of energy recovery equipment or variable frequency pumps in reverse osmosis plants (Fritzmann 2007).

For seawater reverse osmosis desalination plants, the power costs can account for up to $50 \%$ of the total plant operation and maintenance costs (Younos 2003). The following examples are for the largest reverse osmosis desalination plants:

1. The world's largest seawater desalination plant lies in Ashkelon, Israel, which produces about 140 million $\mathrm{m}^{3} \mathrm{yr}^{-1}$ with minimum costs, as low as $0.53 \$$ per cubic meter, due to the use of energy recovery systems (Amy and Lattemann 2017).

2. The world's largest brackish water desalination plant lies in Jordan with a maximum capacity of 185,000 m3/day (Hamoda and Al-Ghusain 2015).

3. Africa's largest desalination plant lies in Algeria; it has a maximum capacity of $230,000 \mathrm{~m}^{3} \mathrm{~d}^{-1}$ (Khan and Ullah 2017).

\section{Reuse of treated wastewater}

The reuse of treated wastewater, which are also national water projects, plays a significant role in water resource management in many countries. As an example, according to Inbar (2007), about $70 \%$ of the wastewater in Israel is treated for agricultural uses. A new standard for unlimited reuse of treated wastewater has been formulated taking into account public health, soil, and hydrological conditions. This standard will enable the reallocation of nearly $50 \%$ of the freshwater resources (about 500 million $\mathrm{m}^{3} \mathrm{yr}^{-1}$ ) from agriculture to the municipal and industrial sectors. In 1999, treated wastewa- ter in Israel constituted about $22 \%$ of the consumption by agriculture, and $40 \%$ in 2005 . It was estimated that treated wastewater will constitute approximately $50 \%$ of agricultural consumption by 2020 .

\section{Inter-Basin Water Transfers (IBWTs)}

Inter-Basin Water Transfer (IBWTs) has been defined as the transfer of the surplus water from a basin which has excess water to another basin which has a shortage of water at the international level, or from one region to another region at the national level (Davies 1992). Tockner and Zarfl (2016) conducted some research on IBWTs worldwide and estimated that about $1100 \times 109 \mathrm{~m}^{3}$ of water was diverted annually through IBWTs, which represented around $20 \%$ of the global water withdrawals. Diversion of water through IBWTs has multi-disciplinary aspects. These may include political and legal situations, environmental impacts, cultural issues, and economic feasibility as a result of the high costs of the installations accompanying IBWTs such as diversion channels, tunnels through mountains, dams, pumping stations, siphon structures, and relocation of residents.

China and India make use of IBWTs on a very large scale, as presented in Table 1. In China, IBWTs connect national rivers, while in India IBWTs have two components, the first for connecting national rivers and the second for connecting rivers that India shares with other countries.

It is also worth mentioning that IBWTs in southern Africa are good examples of benefit-sharing as follows:

1. The Gauteng region in South Africa relies on five inter basin water transfers to secure its water and energy requirements, which consist of water from the Umbeluzi River basin $\left(350 \times 106 \mathrm{~m}^{3}\right.$ per year), the Orange River basin $\left(690 \times 106 \mathrm{~m}^{3}\right.$ per year), the Maputo River basin $\left(85 \times 106 \mathrm{~m}^{3}\right.$ per year), the Limpopo River basin $\left(550 \times 106 \mathrm{~m}^{3}\right.$ per year), and the Incomati River basin $\left(110 \times 106 \mathrm{~m}^{3}\right.$ per year) (Bourblanc and Blanchon 2014).

2. The Lesotho Highlands Water Project, which began in 1986 and was completed in 2009, aimed to supply water to South Africa and electricity to Lesotho

Table 1. IBWTs Projects in China and India

\begin{tabular}{|c|c|c|}
\hline & China (Shao et al. 2003) & India (Gupta 2008) \\
\hline IBWTs & $\begin{array}{l}\text { The south-to-north water transfer project through east, middle } \\
\text { and west routes. } \\
\text { The middle route alone will cross about } 200 \text { river channels } \\
\text { including the Yellow River on its way to Beijing. }\end{array}$ & $\begin{array}{l}\text { The Peninsular river development „the western areas” which } \\
\text { only link national rivers and the Himalayan river development } \\
\text { "The North-East Part" which links rivers that India shares with } \\
\text { China, Bhutan, Nepal, Pakistan and Bangladesh. }\end{array}$ \\
\hline Costs & $\begin{array}{l}\text { The cost of the first phase of the east and middle routes } \\
\text { construction was estimated at US } \$ 18.7 \text { billion. The total cost } \\
\text { of all the three routes was estimated at US } \$ 60 \text { billion „based } \\
\text { on the year } 2000 \text { prices”. }\end{array}$ & $\begin{array}{l}\text { The total costs were projected to be US } \$ 120 \text { billion „based on } \\
\text { the year } 2006 \text { prices”. }\end{array}$ \\
\hline Benefits & $\begin{array}{l}\text { Transfer of about } 44.8 \times 10^{9} \mathrm{~m}^{3} \text { of water per year by } 2050 \\
\text { through the three routes. }\end{array}$ & $\begin{array}{l}\text { Divert about } 178 \times 10^{9} \mathrm{~m}^{3} \text { of water per year, link } 37 \text { rivers, } \\
\text { construct } 3000 \text { reservoirs, generate } 34000 \mathrm{MW} \text { of hydropower } \\
\text { and irrigate } 35 \text { million hectares. }\end{array}$ \\
\hline
\end{tabular}


through transferring about $950 \times 106 \mathrm{~m}^{3}$ of water per year from the Senqu River in Lesotho to the upper Vaal River in South Africa (Hitchcock, 2015). Both rivers form the headwaters of the Orange River, which is shared by Lesotho, South Africa, Botswana, and Namibia. This project is considered as one of the few successful inter-basin water transfer schemes in the world.

As well as the inter-basin water transfer from the Volga River basin in Western Asia to the Rhine River basin in Europe (Dumont 2009) there have also been attempts to transfer water in the Zambezi River, Okavango River and Mekong River. However, none of them have achieved the same level of success as the Southern African case (Grover 2007).

\section{Virtual Water Trade (VWT)}

The amount of water consumed in the production process of an agricultural or industrial product is called the "Virtual water" embedded in the product (El-Sadek 2010). The concept of a virtual water trade has already been implemented in almost all the countries the world for food security, and can also be implemented for saving great amounts of water. Oki et al. (2003) estimated the virtual water content of crop production in exporting countries "the producing countries" to be about $683 \times 109 \mathrm{~m}^{3}$ per year, while if these crops had been produced in the importing countries, they would require about $1138 \times 109 \mathrm{~m}^{3}$ per year, which means that about $455 \times 109 \mathrm{~m}^{3}$ per year (representing about $8 \%$ of global water) was saved. This situation indicates that the real virtual water content of a product, which depends on the production conditions at the production sites, is often lower than the hypothetical virtual water content of the product if the product had been produced at the consumption sites.

According to Renault (2003), the virtual water content of French maize was around $0.6 \mathrm{~m}^{3} \mathrm{~kg}^{-1}$, while the virtual water content of Egyptian maize was about 1.12 $\mathrm{m}^{3} \mathrm{~kg}^{-1}$. Therefore; transporting $1 \mathrm{~kg}$ of maize from
France to Egypt could save globally about $0.52 \mathrm{~m}^{3}$ of water. In the year 2000, Egypt imported about 5.2 million tons of maize from France. This represented a saving of about 5.8 billion $\mathrm{m}^{3}$ of water (about $10 \%$ of the Egyptian annual water allocation). Therefore, waterscarce countries should import products that require huge quantities of water for their production rather than producing them domestically. By doing so, real water savings can be achieved through relieving the pressure on the scarce water resources worldwide and improving the efficiency of global water use.

\section{Political solutions for conflict resolution in transboundary river basins}

The political solutions which can be applied to overcome any conflict among the basin countries are illustrated in: $(i)$ international water agreements to facilitate cooperation over the shared water, and (ii) the creation of river basin institutions to implement certain issues concerned with the river basin. According to Shlomi (2008), there are 14 issues that characterize all the international water agreements as presented in the constructed chart shown in Figure 2.

Some agreements were based on one issue, while others were based on more than one issue. The contri-

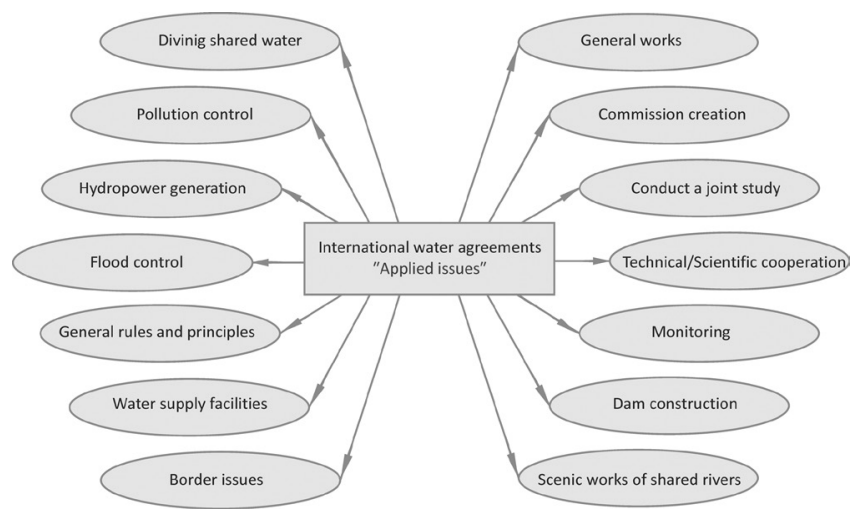

Fig. 2. Applied issues in international water agreements

Table 2. Description of the selected river basins

\begin{tabular}{|l|l|l|}
\hline \multicolumn{1}{|c|}{ River basin } & \multicolumn{1}{|c|}{ Continent } & \multicolumn{1}{c|}{ Description } \\
\hline Orange-Senqu & Africa & $\begin{array}{l}\text { The Orange Senqu River basin is the most developed of all the basins in Southern Africa. It is a recipient } \\
\text { basin for three inter basin water transfers and a donor basin for three inter basin transfers, with four intra- } \\
\text { basin transfers (Turton 2005). }\end{array}$ \\
\hline Aral Sea & Asia & $\begin{array}{l}\text { The environmental problems of the Aral Sea basin are among the worst in the world, in which water } \\
\text { diversions, agricultural practices, and industrial wastes resulted in the disappearence of parts of the sea, } \\
\text { salinization, and organic and inorganic pollution (Wolf 2009). }\end{array}$ \\
\hline Rhine & Europe & $\begin{array}{l}\text { The Rhine River basin has the most important industrial areas in the world with about 30 \% of the world } \\
\text { production of chemical substances (Brack and Herráez 2015). }\end{array}$ \\
\hline Columbia & North America & $\begin{array}{l}\text { The Columbia River basin represents the transboundary water along the United States - Canada } \\
\text { boundaries. }\end{array}$ \\
\hline La Plata & South America & $\begin{array}{l}\text { The La-Plata River basin includes the most important industrialized areas of Latin America, with high } \\
\text { rates of population growth (Rucks 2003). }\end{array}$ \\
\hline
\end{tabular}




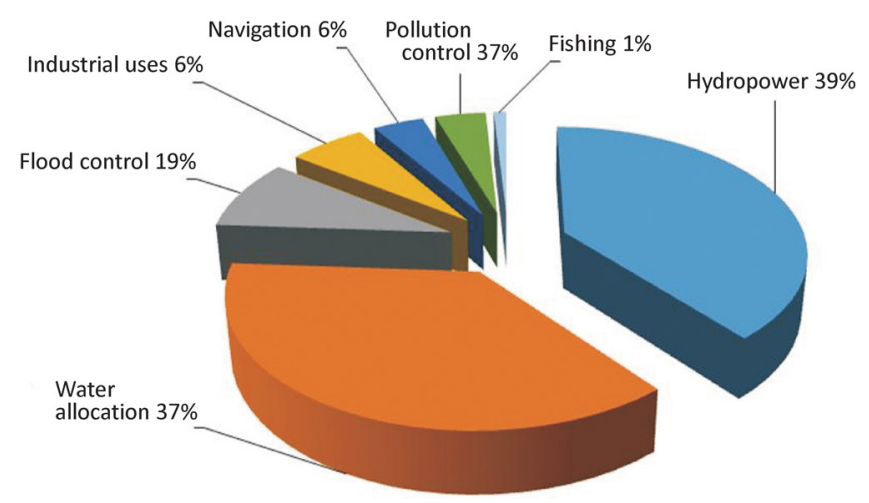

Fig. 3. Contribution of different issues adopted in water agreements during the 20th century

bution of each issue in such water agreements was analysed by Jägerskog (2006), who illustrated that hydropower generation projects were of primary importance and made the maximum contribution in water agreements, followed in second place by water allocation issues, while other issues made minimum contributions in international water agreements, as introduced in Figure 3.

In order to make a comparison between the political solutions for conflict resolution in transboundary river basins all over the world we selected the most important basin in each continent as an example. The selection was based on the following criteria: (i) economic importance of the basin, (ii) environmental importance of the basin, and (iii) development of the basin as illustrated in Table 2. The constructed Table 3. indicates the characteristics of the selected basins, based on data from Wolf (2002) and FAO (2016).

\section{Discussion}

\section{Analyses of technical solutions}

A comparison between the four selected alternative water resources was carried out to identify the advantages, disadvantages, and the most applicable solutions for overcoming such disadvantages, as introduced in Table 4.

Table 3. Characteristics of the selected river basins

\begin{tabular}{|c|c|c|c|c|c|c|c|c|c|}
\hline \multirow{3}{*}{ River basin } & \multirow{3}{*}{$\begin{array}{c}\text { Basin } \\
\text { area } \\
\mathrm{km}^{2}\end{array}$} & \multirow{3}{*}{$\begin{array}{l}\text { Sharing } \\
\text { countries }\end{array}$} & \multirow{2}{*}{\multicolumn{2}{|c|}{ Area in basin }} & \multirow{3}{*}{$\begin{array}{l}\text { Population } \\
\text { thousands }\end{array}$} & \multirow{3}{*}{$\begin{array}{l}\text { Water per capita } \\
\qquad \mathrm{m}^{3} \mathrm{yr}^{-1}\end{array}$} & \multicolumn{3}{|c|}{ Water resources } \\
\hline & & & & & & & Internal & Total & Depend. \\
\hline & & & $\mathrm{km}^{2}$ & $\%$ & & & \multicolumn{2}{|c|}{$\mathrm{km}^{3} \mathrm{yr}^{-1}$} & $\%$ \\
\hline \multirow[t]{4}{*}{ Orange-Senqu } & \multirow[t]{4}{*}{945500} & South Africa & 563900 & 59.65 & 50460 & 1019 & 44.8 & 51.4 & 13 \\
\hline & & Namibia & 240200 & 25.40 & 2324 & 7625 & 6.16 & 17.72 & 65 \\
\hline & & Botswana & 121400 & 12.85 & 2031 & 6027 & 2.4 & 12.24 & 80 \\
\hline & & Lesotho & 19900 & 2.10 & 2194 & 1377 & 5.2 & 3 & 0 \\
\hline \multirow[t]{8}{*}{ Aral Sea } & \multirow[t]{8}{*}{1231400} & Kazakhstan & 424400 & 34.46 & 16207 & 6633 & 64.4 & 107.5 & 40 \\
\hline & & Uzbekistan & 382600 & 31.07 & 27760 & 1760 & 16.34 & 48.87 & 80 \\
\hline & & Tajikistan & 135700 & 11.02 & 6977 & 3140 & 63.5 & 21.9 & 0 \\
\hline & & Kyrgyzstan & 111700 & 9.07 & 5393 & 4380 & 48.9 & 23.6 & 0 \\
\hline & & Afghanistan & 104900 & 8.52 & 32358 & 2019 & 47.2 & 65.3 & 29 \\
\hline & & Turkmenistan & 70000 & 5.68 & 5105 & 4852 & 1.4 & 24.8 & 97 \\
\hline & & China & 1900 & 0.15 & 1378506 & 2060 & 2813 & 2840 & 1 \\
\hline & & Pakistan & 200 & 0.01 & 176745 & 1396 & 55 & 246.8 & 78 \\
\hline \multirow[t]{9}{*}{ Rhine } & \multirow[t]{9}{*}{172900} & Germany & 97700 & 56.49 & 82163 & 1874 & 107 & 154 & 31 \\
\hline & & Switzerland & 24300 & 14.05 & 7702 & 6946 & 40.4 & 53.5 & 24 \\
\hline & & France & 23100 & 13.34 & 63126 & 3343 & 200 & 211 & 5 \\
\hline & & Belgium & 13900 & 8.03 & 10754 & 1702 & 12 & 18.3 & 34 \\
\hline & & Netherlands & 9900 & 5.75 & 16665 & 5461 & 11 & 91 & 88 \\
\hline & & Luxembourg & 2500 & 1.46 & 516 & 6008 & 1 & 3.1 & 68 \\
\hline & & Austria & 1300 & 0.76 & 8413 & 9236 & 55 & 77.7 & 29 \\
\hline & & Liechtenstein & 200 & 0.09 & 36 & - & - & - & - \\
\hline & & Italy & 70 & 0.04 & 60789 & 3147 & 182.5 & 191.3 & 5 \\
\hline \multirow[t]{2}{*}{ Columbia } & \multirow[t]{2}{*}{668400} & USA & 566500 & 84.75 & 313085 & 9802 & 2818 & 3069 & 8 \\
\hline & & Canada & 101900 & 15.24 & 34350 & 84483 & 2850 & 2902 & 2 \\
\hline \multirow[t]{5}{*}{ La-Plata } & \multirow[t]{5}{*}{2954500} & Brazil & 1379300 & 46.69 & 196655 & 41865 & 5418 & 8233 & 34 \\
\hline & & Argentina & 817900 & 27.68 & 40765 & 19968 & 276 & 814 & 66 \\
\hline & & Paraguay & 400100 & 13.54 & 6568 & 51157 & 94 & 336 & 72 \\
\hline & & Bolivia & 245100 & 8.30 & 10088 & 61707 & 303.5 & 622.5 & 51 \\
\hline & & Uruguay & 111600 & 3.78 & 3380 & 41124 & 59 & 139 & 58 \\
\hline
\end{tabular}


Table 4. Comparison between the studied alternative water resources

\begin{tabular}{|l|l|l|l|}
\hline \multicolumn{1}{|c|}{$\begin{array}{c}\text { Alternative water } \\
\text { resources }\end{array}$} & \multicolumn{1}{|c|}{ Advantages } & \multicolumn{1}{|c|}{ Disadvantages } \\
\hline Desalination & $\begin{array}{l}\text { Desalination plants can provide fresh } \\
\text { drinking water in the areas which } \\
\text { have no potable water supplies. }\end{array}$ & $\begin{array}{l}\text { The energy required for } \\
\text { desalination is high. }\end{array}$ & $\begin{array}{l}\text { Ssing of energy recovery devices; as well } \\
\text { as using renewable energy sources such } \\
\text { as solar, wind and nuclear energies. }\end{array}$ \\
\hline $\begin{array}{l}\text { Reuse of Treated } \\
\text { Wastewater }\end{array}$ & $\begin{array}{l}\text { Reuse of treated wastewater can } \\
\text { be a better solution compared to } \\
\text { desalination at least for restricted } \\
\text { agricultural purposes. }\end{array}$ & $\begin{array}{l}\text { There are some hazards to } \\
\text { public health. }\end{array}$ & $\begin{array}{l}\text { Using treated wastewater should be under } \\
\text { regulations and guidelines for health } \\
\text { protection. }\end{array}$ \\
\hline $\begin{array}{l}\text { Inter-Basin Water } \\
\text { Transfers }\end{array}$ & $\begin{array}{l}\text { These projects are good examples } \\
\text { of benefit-sharing, as in southern } \\
\text { Africa, China, and India. }\end{array}$ & $\begin{array}{l}\text { High costs of construction } \\
\text { and operation, as well as } \\
\text { environmental and political } \\
\text { effects. }\end{array}$ & $\begin{array}{l}\text { The funding can be borrowed from the } \\
\text { World Bank, as in the case of the Lesotho } \\
\text { Highlands Water Project in Southern Africa, } \\
\text { and the basin countries should share the } \\
\text { benefits and costs as well. }\end{array}$ \\
\hline Virtual Water Trade & $\begin{array}{l}\text { Relieving the pressure on scarce } \\
\text { water recourses by adopting a } \\
\text { policy to grow and export products } \\
\text { which require relatively low water } \\
\text { and import products with high water } \\
\text { requirements. }\end{array}$ & $\begin{array}{l}\text { Increase of global food prices. } \\
\text { Land acquisition for agricultural purposes } \\
\text { in countries which have excess water and } \\
\text { less development, as well as increase } \\
\text { global food prices can be avoided through } \\
\text { some of protocols between the exporting } \\
\text { and importing countries. }\end{array}$ \\
\hline
\end{tabular}

Table 5. Conflict causes, conflict resolutions and comments for the selected basins

\begin{tabular}{|c|c|c|c|}
\hline $\begin{array}{l}\text { River } \\
\text { basin }\end{array}$ & Conflict causes & Conflict resolution & Author's comments \\
\hline $\begin{array}{l}\text { Orange- } \\
\text { Senqu }\end{array}$ & $\begin{array}{l}\text { Political boundaries between } \\
\text { South Africa and Namibia } \\
\text { (Ashton 2000). }\end{array}$ & $\begin{array}{l}\text { In 2000, an agreement between Botswana, } \\
\text { Lesotho, Namibia, and South Africa was signed } \\
\text { for the establishment of the Orange-Senqu river } \\
\text { commission (Turton et al. 2004). }\end{array}$ & $\begin{array}{l}\text { The water protocol of the Southern African } \\
\text { development community plays a role as } \\
\text { a legal framework for the development of } \\
\text { water cooperation in many of international } \\
\text { river basins in Southern Africa. }\end{array}$ \\
\hline Aral Sea & $\begin{array}{l}\text { Water scarcity, water } \\
\text { allocation approaches from } \\
\text { the Soviet Era and water } \\
\text { sharing issues such as } \\
\text { sharing the costs of basin } \\
\text { management (Dukhovny and } \\
\text { Sokolov 2003). }\end{array}$ & $\begin{array}{l}\text { In 1992, an agreement for water allocations was } \\
\text { signed with the establishment of the interstate } \\
\text { commission for water coordination. } \\
\text { In 1993, establishment of the interstate council } \\
\text { for the Aral Sea and the international fund for } \\
\text { saving the Aral Sea. } \\
\text { In } 1997 \text { these two bodies were merged into one } \\
\text { body (Dukhovny and Sokolov 2003). }\end{array}$ & $\begin{array}{l}\text { The difficult and complex conditions } \\
\text { that followed the collapse of the Soviet } \\
\text { Union harmed attempts to provide regular } \\
\text { satisfactory water demands because the } \\
\text { sharing countries were not only working } \\
\text { together in planning, but also in operating } \\
\text { and managing the basin. }\end{array}$ \\
\hline Rhine & $\begin{array}{l}\text { Navigation and water } \\
\text { pollution because of } \\
\text { the location of the most } \\
\text { important plants for chemical } \\
\text { production along the Rhine } \\
\text { River (Frijters 2003). }\end{array}$ & $\begin{array}{l}\text { The Central Commission for navigation on the } \\
\text { Rhine has been established since } 1815 . \\
\text { An International Commission for the protection } \\
\text { of the Rhine against pollution was established in } \\
1950 . \\
\text { An International Commission for the hydrology of } \\
\text { the Rhine basin was established in } 1970 . \\
\text { A convention for the protection of the Rhine } \\
\text { against chemical and chloride pollution was } \\
\text { signed in } 1976 \text { (Frijters 2003). }\end{array}$ & $\begin{array}{l}\text { Sustainable management of the Rhine } \\
\text { basin needs a river basin approach for the } \\
\text { whole basin, with integrated water resource } \\
\text { management as the task of one institution } \\
\text { to avoid duplicating work among the existing } \\
\text { institutions. }\end{array}$ \\
\hline Columbia & $\begin{array}{l}\text { Construction of the Libby } \\
\text { dam in the USA in the 1950s } \\
\text { and the McNaughton plan } \\
\text { for hydropower through a } \\
\text { diversion of a part of the } \\
\text { Columbia River in Canada } \\
\text { into the Fraser River } \\
\text { (Muckleston 2003). }\end{array}$ & $\begin{array}{l}\text { In 1964, the Columbia River treaty was } \\
\text { signed to achieve equal sharing of benefits } \\
\text { from hydropower and flood control with the } \\
\text { establishment of a US army corps of engineers } \\
\text { and the Bonneville power administration } \\
\text { (Muckleston 2003). }\end{array}$ & $\begin{array}{l}\text { The Columbia River treaty focused on } \\
\text { certain projects without taking any account } \\
\text { of the complexities of any alternative } \\
\text { projects. }\end{array}$ \\
\hline La-Plata & $\begin{array}{l}\text { Control over the Guairá } \\
\text { Falls „the land where the } \\
\text { Itaipu dam now exists", was } \\
\text { a source of disagreement } \\
\text { between Brazil and } \\
\text { Paraguay (Elhance 1999). }\end{array}$ & $\begin{array}{l}\text { In 1969, the La-Plata basin treaty was signed and } \\
\text { followed by the establishment of the coordinating } \\
\text { intergovernmental committee of the La-Plata } \\
\text { basin countries in Buenos Aires in } 1973 \text { (Varady } \\
\text { et al. 1999). } \\
\text { Many bilateral treaties between the sharing } \\
\text { countries and hydroelectric projects had come out } \\
\text { of the } 1969 \text { multilateral agreement (Gilman 2008). }\end{array}$ & $\begin{array}{l}\text { The development of hydropower, navigation } \\
\text { infrastructure and the introduction of } \\
\text { intensive agricultural practices caused } \\
\text { severe environmental degradation } \\
\text { throughout the basin. }\end{array}$ \\
\hline
\end{tabular}




\section{Analyses of political solutions}

Conflicts over water in transboundary river basins can be solved through reaching good water agreements to outline rules and regulations that govern the behavior of basin countries towards the shared river, or setting up detailed solutions for common conflicts. Mostert (2003) illustrated that strained relations among basin countries could hinder the achievement of necessary agreements, as in the Tigris-Euphrates and the Ganges-Brahmaputra-Mechna basins, while in some cases water agreements can be reached despite strained relations, as in the Indus and the Senegal basins. On the other hand, conflicts can arise with existing water treaties due to the river flow variability, as in the case of the 1997 droughts in the Ganges basin which threatened the 1996 water treaty between India and Bangladesh (Salman 2002).

The international management of the selected basins was analysed, as introduced in Table 5, through conflict causes, mechanisms of dispute settlement, followed by our comments about the management of each basin.

From the table, it is clear that water agreements should be based on: (i) flexibility for introducing the needed modifications with time, (ii) mechanisms of water allocations based on reasonable use of water, and (iii) water institutions should have specific tasks in the river basin.

After analysing the technical and political solutions implemented for solving the water problems in international river basins all over the world the percentages of implementing these solutions in the basins of each continent were estimated as the ratio of transboundary river basins implementing the analysed solutions to the total number of the transboundary river basins in each continent. The results are presented in Table 6.

From this table one can conclude that national water projects, which include desalination, reuse of treated wastewater and national water transfers, implemented to partially overcome the problems of water scarcity in some of the basin countries, are the lowest in Africa and Asia compared to the remaining continents owing to the huge national investments needed for these projects. However, international water transfer projects have also been implemented to overcome the problems of water scarcity in some basins where the sharing countries are extremely dependent on freshwater resources. These international water projects in Africa and Asia are funded through international donors.

With respect to the political solutions for conflict resolution as indicated in Table 6, roughly $30 \%$ of the transboundary river basins worldwide have water agreements; most of them based on equitable and reasonable utilization of the water among the basin countries, associated with the avoidance of harm.

\section{The River Nile basin characteristics and situations}

The River Nile, which is the longest river in the world; begins in the Equatorial Lakes Plateau and descends towards the Mediterranean Sea on the northern borders of Egypt, with a total length of more than 6800 $\mathrm{km}$ (El-Fadel 2003). The Nile basin is shared by eleven countries, as illustrated in Figure 4, occupies more than 3.1 million $\mathrm{km}^{2}$ (Abtew and Melesse 2014), and serves a population of around 426 million, as given in the constructed Table 7 , with additional characteristics about the basin countries.

From the above-mentioned table, we can observe that Egypt, "the downstream country", which has the lowest annual water per capita in the basin, is heavily dependent on the Nile water (97\%) in comparison with the other basin countries, especially in Ethiopia and Rwanda where dependency on the Nile water is nil. Hence, the great incompatibility, unfairness and disparity in the sharing of Nile water among the basin countries create sources of conflicts within the basin (Yitayew and Melesse 2011).

The modern history of international water relations in the Nile basin indicates the existence of cooperation as well as conflicts among the basin countries. Cooperation in the Nile basin, concerned with water aspects can be placed into three categories: (i) bilateral or trilateral agreements from the late of the nineteenth century

Table 6. The percentages of transboundary river basins implementing technical and political solutions for solving the water problems per each continent

\begin{tabular}{|c|c|c|c|c|c|c|}
\hline \multirow{3}{*}{ Continent } & \multirow{3}{*}{$\begin{array}{c}\text { Number of Transboundary } \\
\text { River Basins }{ }^{a}\end{array}$} & \multirow{3}{*}{$\begin{array}{c}\text { Water } \\
\text { Agreements }^{\mathrm{b}}\end{array}$} & \multicolumn{4}{|c|}{ Water Projects } \\
\hline & & & \multicolumn{3}{|c|}{ National } & \multirow{2}{*}{$\begin{array}{c}\text { International } \\
\text { Inter-Basin Water } \\
\text { Transfer }^{\mathrm{T}}\end{array}$} \\
\hline & & & $\begin{array}{c}\text { Water } \\
\text { Recycling }\end{array}$ & Desalination $^{c}$ & Water Transfer ${ }^{d}$ & \\
\hline Africa & 63 & $25 \%$ & $13 \%$ & $9 \%$ & $3 \%$ & $5 \%$ \\
\hline Asia & 73 & $23 \%$ & $35 \%$ & $27 \%$ & $7 \%$ & $3 \%$ \\
\hline Europe & 67 & $30 \%$ & $88 \%$ & $65 \%$ & $52 \%$ & $1.5 \%$ \\
\hline N. America & 46 & $41 \%$ & $81 \%$ & $35 \%$ & $22 \%$ & 0 \\
\hline S. America & 37 & $30 \%$ & $86 \%$ & $56 \%$ & $15 \%$ & 0 \\
\hline
\end{tabular}

Data according to: a - Glennie and Bjørnsen (2016), b - Iyob (2010), c - Escobar (2010), d - Thatte (2005), e - Grover (2007) and Dumont (2009). 
Table 7. Characteristics of the Nile River basin countries

\begin{tabular}{|c|c|c|c|c|c|c|c|c|c|}
\hline \multirow{3}{*}{ Country } & \multirow{2}{*}{\multicolumn{2}{|c|}{ Area $^{a}$}} & \multirow{3}{*}{$\begin{array}{c}\text { Population }^{b} \\
\text { thousands }\end{array}$} & \multirow{3}{*}{$\begin{array}{c}\text { Water per capitab } \\
\mathrm{m}^{3} \mathrm{yr}^{-1}\end{array}$} & \multicolumn{3}{|c|}{ Water Resources ${ }^{\mathrm{b}}$} & \multicolumn{2}{|c|}{ Agricultural area $^{c}$} \\
\hline & & & & & Internal & Total & Depend. ratio & Irrigated & Irrigable \\
\hline & $\mathrm{km}^{2}$ & $\%$ & & & \multicolumn{2}{|c|}{$\mathrm{km}^{3} \mathrm{yr}^{-1}$} & $\%$ & \multicolumn{2}{|c|}{$\mathrm{km}^{2}$} \\
\hline Burundi & 13260 & 0.4 & 8575 & 1462 & 10.1 & 12.5 & 20 & 0.5 & 800 \\
\hline D.R.Congo & 22143 & 0.7 & 67758 & 18935 & 900 & 1283 & 30 & 0.8 & 100 \\
\hline Egypt & 326751 & 10.5 & 82537 & 694 & 1.8 & 57.3 & 97 & 29232 & 44200 \\
\hline Eritrea & 24921 & 0.8 & 5415 & 1163 & 2.8 & 6.3 & 56 & 58 & 1500 \\
\hline Ethiopia & 365117 & 11.7 & 84734 & 1440 & 122 & 122 & 0 & 321 & 22200 \\
\hline Kenya & 46229 & 1.5 & 41610 & 738 & 20.7 & 30.7 & 33 & 98 & 1800 \\
\hline Uganda & 231366 & 7.4 & 34509 & 1913 & 39 & 66 & 41 & 91 & 2020 \\
\hline Rwanda & 19876 & 0.7 & 10934 & 868 & 9.5 & 9.5 & 0 & 33 & 1500 \\
\hline Sudan & \multirow{2}{*}{1978506} & \multirow{2}{*}{63.6} & \multirow{2}{*}{44632} & \multirow{2}{*}{1445} & \multirow{2}{*}{30} & \multirow{2}{*}{64.5} & \multirow{2}{*}{77} & \multirow{2}{*}{19303} & \multirow{2}{*}{27500} \\
\hline S. Sudan & & & & & & & & & \\
\hline Tanzania & 84200 & 2.7 & 46218 & 2083 & 84 & 96.3 & 13 & 141 & 300 \\
\hline Total & 3112369 & 100 & 426922 & & & & & 49278.3 & 101920 \\
\hline
\end{tabular}

Data according to: a - Abtew and Melesse (2014), b - FAO (2016), c - Appelgren (2000).

which emphasized the acquired natural and historical water rights for Egypt and Sudan (Cascão 2009), (ii) water initiatives and institutions from the 1960s such as HYDROMET, TECCONILE and the Nile 2002 Conference Series (Kagwanja 2007; Swain 2011), and (iii) attempts for basin-wide cooperation from the late of 1990s, represented by the Nile Basin Initiative - NBI (Di Nunzio 2013) and the Cooperative Framework Agreement (CFA) for equitable water shares among the basin countries (Hilhorst 2016).

The existence of the above-mentioned cooperation categories within the Nile basin has not completely excluded the emergence of hydro-political disputes among the basin countries. These dispute have passed through different stages beginning with the insistence of the upstream countries, after their independence in the early 1960s, on the illegality of the historical Nile water agreements that were signed by the colonial powers and granted Egypt absolute control over the Nile River (Di Nunzio 2013); passing through Egyptian concerns about the potential effects of any water project on the Blue Nile basin in Ethiopia upon the Nile flow to Egypt. These concerns persuaded Egypt's politicians to try to prevent any water project on the Blue Nile basin in Ethiopia in the late of 1970s and the early 1990s (Swain 1997; Rau 2011). Further tension arose when hydro-political relations within the basin reached a critical level after the failure of negotiations over the CFA-Entebbe and the refusal of Egypt and the Sudan to sign the agreement (Islam and Susskind 2015). The situation worsened with the Ethiopian announcement to execute the Grand Ethiopian Renaissance Dam (GERD) on the Blue Nile without prior notification and consultation with the downstream countries (Egypt and the Sudan). The construction of such a dam could threaten Egyptian water security (Abtew 2014).
Besides the above-mentioned hydro-political situations, the Nile basin is unique in its hydrological conditions that can be summarized in the loss of huge amounts of Nile income through evaporation. Although rainfall over the Nile basin is approximately 1661 billion cubic metres (BCM) per year, the evaporation losses amount to about $544 \mathrm{BCM} \mathrm{yr}^{-1}$ from the Sudd swamps (NBI 2012), about $120 \mathrm{BCM} \mathrm{yr}^{-1}$ from

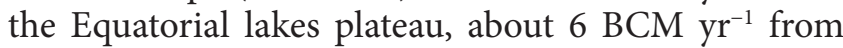
Bahr el Jebel into Bahr el Ghazal swamps (Sutcliffe and Parks 1999), about $500 \mathrm{BCM} \mathrm{yr}^{-1}$ from Bahr el Ghazal basin (Shahin 1985), about $10 \mathrm{BCM} \mathrm{yr}^{-1}$ from the Machar marshes swamps in the Sobat basin, about $14 \mathrm{BCM} \mathrm{yr}^{-1}$ from Bahr el Ghazal into Bahr el Ghazal swamps and about $14 \mathrm{BCM} \mathrm{yr}^{-1}$ from Bahr el Jebel and the Bahr el Zeraf swamps (Blackmore and Whittington 2008; Kirby et al. 2010). Blackmore and Whittington (2008) indicated that evaporation from the huge manmade reservoirs is about 15-20 $\mathrm{BCM} \mathrm{yr}^{-1}$ and the conveyance losses along the Nile course are about 20-30 BCM yr ${ }^{-1}$. Also, according to Kirby et al. (2010), about $13 \%\left(216 \mathrm{BCM} \mathrm{yr}^{-1}\right)$ of the total rainfall in the Nile basin is evaporated from agricultural systems (10\% from rain-fed agriculture and 3\% from irrigated agriculture).

The above-mentioned losses represent approximately $90 \%$ (about $1480 \mathrm{BCM} \mathrm{yr}^{-1}$ ) of the total rainfall over the basin. These huge losses require serious technical cooperation among the basin countries to minimize and control them through some engineering approaches.

After reviewing the Nile River basin characteristics and situations, identifying the most applicable technical solutions for water scarcity problems and understanding the geographical conditions of the basin countries we can conclude that desalination is particularly applicable for some of the basin countries, especially Egypt, which has a shoreline of about $1000 \mathrm{~km}$ in length; on the Mediterranean Sea coast in the north and the Red 
Sea coast in the east (Shahin 1985). However, a major constraint which the implementation of desalination in Egypt, as a developing country, must overcome, is the huge national investment in both the construc-

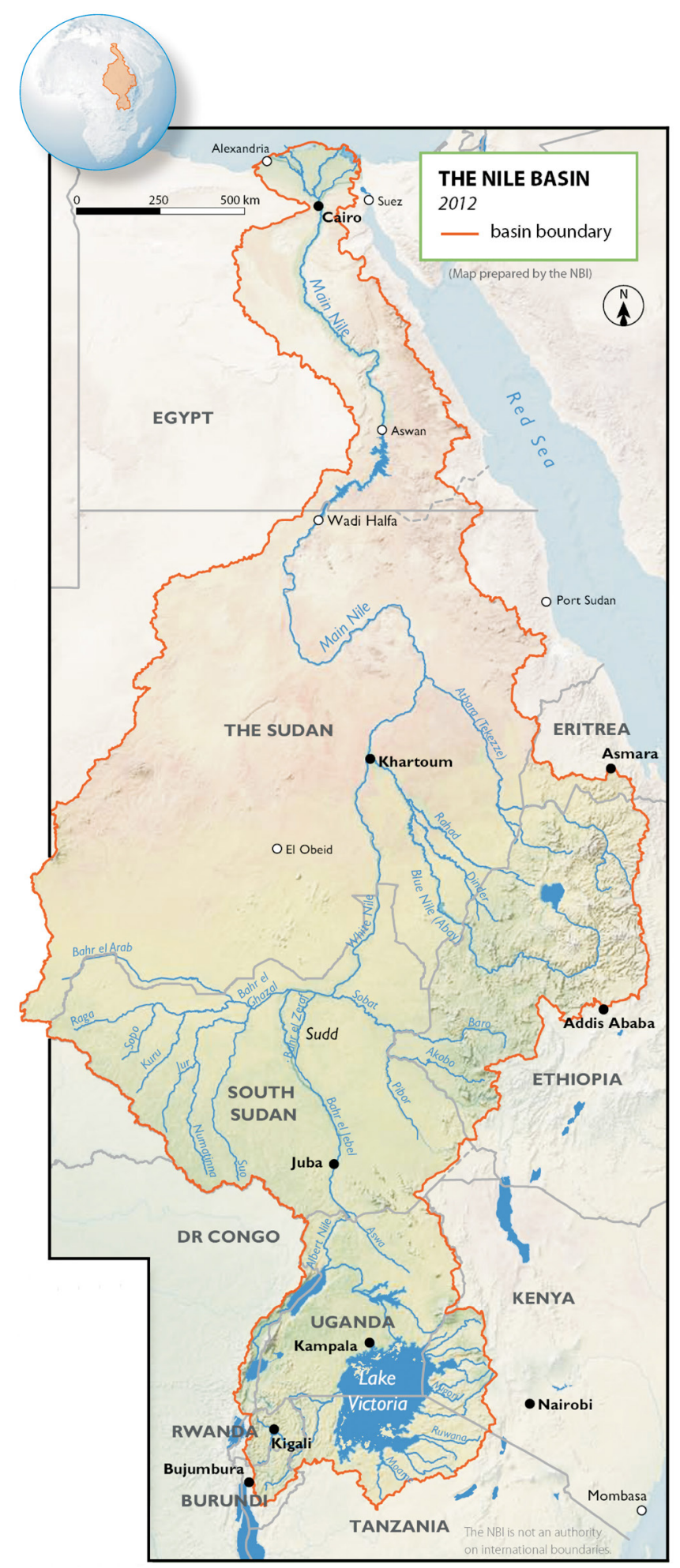

Fig. 4. Map of the Nile River basin (NBI 2012) tion and operation of a desalination plant. According to (Greenlee and Moulin 2009); based on the prices of 2007, capital construction costs for a desalination plant fell between US\$ 600-800 per cubic metre, while operation and maintenance costs are in the range of US\$ $900-1200 \mathrm{~m}^{-3} \mathrm{yr}^{-1}$. These huge investments cannot be sustained by any developing country. Moreover, the desalination process would not be able to provide the necessary large quantities of freshwater for the current and future generations.

On the other hand, with the exception for southern Africa, international water transfers through the construction of channels to link unconnected rivers have not yet occurred on a large scale in Africa. However, after studying several transboundary river basins all over the world we found that in countries that heavily depend on freshwater resources from rivers, such as Egypt, the most suitable non-conventional solution for providing the needed large amounts of freshwater for current and future generations would be an international water transfer from another basin that has an excess of water. International water transfers are projects with multiple purposes such as: (i) irrigation development along the linking channel between the two rivers, and (ii) an increase of regional hydropower generation. Such international projects, based on international cooperation, are the most widely supported by international donors, especially the World Bank which willingly participates in the financing of such international projects.

\section{Conclusions}

After the foregoing review and analysis of the experiences implemented in transboundary river basins worldwide, the following conclusions can be drawn:

1. There is a great need for the establishment of clear criteria to achieve the necessary balance between the rights of both estuaries and source countries in order to avoid any conflicts among them.

2. The most successful water agreements in around 80 transboundary river basins all over the world were based on the principle of equitable and reasonable utilization of the river water associated with the prevention of causing harm to the other basin countries. This approach is the most recommended for other conflicted basins, such as the Nile basin.

3. Water agreements should be based on: (i) flexibility for introducing the necessary modifications over time, (ii) mechanisms of water allocations based on reasonable use of water, and iii) water institutions should have specific tasks in the river basin.

4. A major problem facing the management of several transboundary river basins, such as the Tigris-Euphrates basin (between Turkey, Syria and Iraq) and 
the Nile basin (between Egypt and Ethiopia), is the absence of the principle of prior notification and consultation before the execution of any project on the river. Hence, water resource scientists and experts, through cooperation with specialists in international law, should create a framework for a strict and mandatory international law prohibiting the implementation of any project on a transboundary river basin without prior consultation with the other countries.

5. The Nile River basin has a special quality in the huge amounts of water losses which reach approximately $1480 \mathrm{BCM} \mathrm{yr}^{-1}$, representing roughly $90 \%$ of the whole basin income. Therefore, specialized technical care must be considered for minimizing such huge amounts of losses in the above mentioned subbasins of the Nile basin.

\section{References}

Abtew W., 2014, Land and Water in the Nile Basin, [in:] Melesse A.M., Abtew W., Setegn S.G., (eds), Nile River Basin: Eco-hydrological Challenges, Climate Change and Hydropolitics, Springer, Dordrecht: 119-129.

Abtew W., Melesse A.M., 2014, The Nile River Basin, [in:] Melesse A.M., Abtew W., Setegn S.G., (eds), Nile River Basin: Eco-hydrological Challenges, Climate Change and Hydropolitics, Springer, Dordrecht: 7-21.

Amy G., Ghaffour N., Li Z., Francis L., Linares R.V., Missimer T., Lattemann S., 2017, Membrane-based seawater desalination: Present and future prospects, Desalination 401: 16-21.

Appelgren B., Klohn W., Alam U., 2000, Water and agriculture in the Nile basin. Nile Basin Initiative Report to IC$\mathrm{CON}, \mathrm{FAO}$, Rome, $58 \mathrm{pp}$.

Ashton P.J., 2000, Southern African water conflicts: Are they inevitable or preventable?, Afr. Dialog. Monogr. Ser. (Durban) 2: 1-26.

Blackmore D., Whittington D., 2008, Opportunities for cooperative water resources development on the Eastern Nile: Risks and Rewards. Final Report to the Eastern Nile Council of Ministers, Nile Basin Initiative, Entebbe, 83 pp.

Bourblanc M., Blanchon D., 2014, The challenges of rescaling South African water resources management: Catchment Management Agencies and inter basin transfers, J. Hydrol. 519: 2381-2391.

Brack W., Altenburger R., Schüürmann G., Krauss M., Herráez D.L., 2015, The Solutions project: Challenges and responses for present and future emerging pollutants in land and water resources management, Sci. Total Environ. 503: 22-31.

Cascão A.E., 2009, Changing Power Relations in the Nile River Basin: Unilateralism vs. Cooperation?, Water Alternatives 2(2): 245-268.
Davies B.R., Thoms M., Meador M., 1992, The ecological impacts of inter-basin water transfers and their threats to river basin integrity and conservation, Aquat Conserv. 2(4) 325-349.

Di Nunzio J., 2013, Conflict on the Nile: The future of transboundary water disputes over the world's longest river, Future Directions International Strategic Analysis Paper, Dalkeith, 9 pp.

Dukhovny V., Sokolov V., 2003, Lessons on cooperation building to manage water conflicts in the Aral Sea Basin, UNESCO-IHP, Paris, 50 pp.

Dumont H.J., 2009, A Description of the Nile Basin, and a Synopsis of Its History, Ecology, Biogeography, Hydrology, and Natural Resources, [in:] Dumont H.J. (ed.), The Nile: Origin, Environments, Limnology and Human Use. Monographiae Biologicae Vol. 89, Springer, Dordrecht: $1-21$.

El-Fadel M., El-Sayegh Y., El-Fadl K., Khorbotly D., 2003, The Nile river basin: A case study in surface water conflict resolution, J. Nat. Resource. Life Sci. Educ. 32: 107-117.

Elhance A.P., 1999, Hydropolitics in the 3rd World: Conflict and cooperation in international river basins, US Institute of Peace Press, Washington, 315 pp.

El-Sadek A., 2010, Virtual Water Trade as a Solution for Water Scarcity in Egypt, Water Resour. Manage. 24(11): 2437-2448.

Escobar I.C., Schafer A.I., 2010, Sustainable Water for the Future. Water Recycling versus Desalination, Sustainability Science and Engineering Vol. 2, Elsevier, Amsterdam, 444 pp.

[FAO] Food and Agriculture Organization, 2016, AQUASTAT Main Database, Food and agriculture organization of the United Nations (FAO). Retrieved from http:// www.fao.org/nr/water/aquastat/data/query/index.html [accessed 7 February 2018].

Frijters D., Leentvaar J., 2003, Rhine case study, UNESCOIHP, Paris, 33 pp.

Fritzmann C., Löwenberg J., Wintgens T., Melin, T., 2007, State-of-the-art of reverse osmosis desalination, Desalination 216(1-3): 1-76.

Gilman P., Pochat V., Dinar A., 2008, Whither La Plata? Assessing the state of transboundary water resource cooperation in the basin, Nat. Resour. Forum 32: 203-214.

Glennie P., Bertule M., Eynard J., Jaiteh M., Schneider C., Bjørnsen P., 2016, Introduction, [in:] UNEP-DHI and UNEP, Transboundary River Basins: Status and Trends, United Nations Environment Program (UNEP), Nairobi: 117.

Greenlee L.F., Lawler D.F., Freeman B.D., Marrot B., Moulin P., 2009, Reverse osmosis desalination: water sources, technology, and today's challenges, water research, Water Res. 43(9): 2317-2348.

Gupta J., van der Zaag P., 2008, Inter basin water transfers and integrated water resources management: Where engineering science and politics interlock, Phys. Chem. Earth 33(1-2): 28-40. 
Grover V.I. (ed.), 2007, Water: A Source of Conflict or Cooperation?, Science Publishers Inc., Enfield, 360 pp.

Hamoda M.F., Attia N.F., Al-Ghusain I.A., 2015, Performance evaluation of wastewater reclamation plant using ultrafiltration and reverse osmosis, Desalin. Water Treat. 54(11): 2928-2938.

Hilhorst B., 2016, Water management in the Nile basin: A fragmented but effective cooperative regime. Occasional Paper No. 17, Georgetown University in Qatar - Center for International and Regional Studies (CIRS), Doha, 32 pp.

Hitchcock R.K., 2015, The Lesotho Highlands Water Project: Dams, development, and the World Bank, Sociol Anthropol. 3(10): 526-538.

Inbar Y., 2007, New standards for treated wastewater reuse in Israel, [in:] Zaidi M.K. (ed.) Wastewater Reuse-Risk Assessment, Decision-Making and Environmental Security. NATO Science for Peace and Security Series, Springer, Dordrecht: 291-296.

Islam S., Susskind L., 2015, Understanding the water crisis in Africa and the Middle East: How can science inform policy and practice?, Bull. At. Sci. 71(2): 39-49.

Iyob B., 2010, Resilience and adaptability of transboundary rivers: The principle of equitable distribution of benefits and the institutional capacity of the Nile Basin [Dissertation], Oregon State University, Corvallis, 261 pp.

Jägerskog A., Phillips D., 2006, Human development report 2006: Managing transboundary waters for human development. Occasional Paper HDOCPA-2006-08, Human Development Report Office (HDRO), United Nations Development Programme (UNDP), New York, 33 pp.

Jansky L., Pachova N.I., Murakami M., 2004, The Danube: A case study of sharing international waters, Global Environ. Chang. 14(Suppl.): 39-49.

Kagwanja P., 2007, Calming the waters: The East African community and conflict over the Nile resources, J. East. Afr. Stud. 1(3): 321-337.

Muckleston K.W., 2003, International management in the Columbia river system, UNESCO-IHP, Paris, 47 pp.

Khan S.U.-D., Haider S., El-Leathy A., Rana U.A., Danish S.N., Ullah R., 2017, Development and techno-economic analysis of small modular nuclear reactor and desalination system across Middle East and North Africa region, Desalination 406: 51-59.

Kirby M., Mainuddin M., Eastham J., 2010, Water-use accounts in CPWF basins: Model concepts and description, CPWF Working Paper: Basin Focal Project series BFP01. The CGIAR Challenge Program on Water and Food, Colombo, $21 \mathrm{pp}$.

Mostert E., 2003, Conflict and cooperation in international freshwater management: A global review, Int. J. River Basin Management 1(3): 267-278.

[NBI] Nile Basin Initiative, 2012, The state of the Nile River Basin 2012, Nile Basin Initiative, Entebbe, 256 pp.

Oki T., Sato M., Kawamura A., Miyake M., Kanae S., Musiake K., 2003, Virtual water trade to Japan and in the world, [in:] Hoekstra A.Y. (ed.) Virtual water trade. Proceedings of the International Expert Meeting on Virtual Water Trade. Value of Water Research Report Series No 12., IHE, Delft: 221-235.

Rau P.L., 2011, Cooperation in the Eastern Nile Basin [Thesis], The American University in Cairo, Cairo, $121 \mathrm{pp}$.

Renault D., 2003, Value of virtual water in food: Principles and virtues, , [in:] Hoekstra A.Y. (ed.) Virtual water trade. Proceedings of the International Expert Meeting on Virtual Water Trade. Value of Water Research Report Series No 12., IHE, Delft: 77-91.

Rucks J., 2003, Experience and role of the organization of American states in transboundary river basin management in Latin America, [in:] Diaz H.F., Morehouse B.J. (eds), Climate and water: Transboundary challenges in the Americac, Kluwer Academic Publishers, Dordrecht: 41-57.

Salman S., Uprety K., 2002, Conflict and cooperation on South Asia's international rivers: A legal perspective, The World Bank, Washington, 217 pp.

Shao X., Wang H., Wang Z., 2003, Inter basin transfer projects and their implications: A China case study, Int. J. River Basin Manage. 1(1): 5-14.

Shlomi D., 2008, Treaty principles and patterns: Negotiations over international rivers [Dissertation], Johns Hopkins University, Baltimore, $81 \mathrm{pp}$.

Shahin M., 1985, Hydrology of the Nile Basin. Developments in Water Science Vol. 21, Elsevier Science, Amsterdam, 575 pp.

Sutcliffe J.V., Parks Y.P., 1999, The hydrology of the Nile, IAHS Special Publication No. 5, IAHS Press, Wallingford, $179 \mathrm{pp}$.

Swain A., 1997, Ethiopia, the Sudan, and Egypt: The Nile River dispute, J. Mod. Afr. Stud. 35(4): 675-694.

Swain A., 2011, Challenges for water sharing in the Nile basin: changing geo-politics and changing climate, Hydrol. Sci. J. 56(4): 687-702.

Thatte C.D., 2005, Dams and inter basin water transfer for augmentation of water resources - A review of needs, plans, status and prospects [Keynote lecture], 12th World Water Congress on Water for Sustainable Development Towards Innovative Solutions, (22-25) November 2005, New Delhi, India.

Tockner K., Bernhardt E.S., Koska A., Zarfl C., 2016, A global view on future major water engineering projects, [in:] Hüttl R., Bens O., Bismuth C., Hoechstetter S. (eds), Society - water - technology: A critical appraisal of major water, Springer, Dordrecht: 47-64.

Turton A.R., Meissner R., Mampane P.M., Seremo O., 2004, A hydropolitical history of south Africa's international river basins. Water Research Commission Report No. 1220/1/04, Water Research Commission, Gezina, 454 pp.

Turton A.R., 2005, Water as a source of conflict or cooperation: The case of South Africa and its transboundary rivers, CSIR Report No: ENV-P-CONF 2005-002, 32 pp. 
Varady R.G., Milich L., Ingall R.E., 1999, Post-NAFTA environmental management in the U.S.-Mexico border region: Openness, sustainability, and public participation, Proceedings of the Third Inter-American Dialogue on Water Management, (15-21) March 1999, Panama City, Panama.

Yitayew M., Melesse A.M., 2011, Critical water resources issues in the Nile river basin, [in:] Melesse A.M., (ed.), Nile River Basin: Hydrology, climate and water use, Springer, Dordrecht: 401-416.
Yoffe S., 2002, Basins at Risk: Conflict and cooperation over international freshwater resources, [Dissertation], Oregon State University, Corvallis, $97 \mathrm{pp}$.

Younos T., 2003, The economics of desalination, J. Contemp. Water Res. Educ. 132: 39-45.

Wolf A.T., Giordano T., Meredith A., 2002, Atlas of international freshwater agreements, UNEP, Nairobi, $184 \mathrm{pp}$.

Wolf A.T., Newton J.T., 2009, Case studies of transboundary dispute resolution, [in:] Delli Priscoli J., Wolf A.T. (eds), Managing and transforming water conflicts, Cambridge University Press, Cambridge: 169-248. 